\title{
PENGARUH AKSESIBILITAS DAN CITRA DESTINASI TERHADAP NIAT BERKUNJUNG KEMBALI KE TELAGA TAMBING
}

\author{
TAUFIK TRI NUR HIDAYAT \\ CHALIL \\ MASKURI SUTOMO \\ Program Studi S1 Manajemen, Fakultas Ekonomi, Universitas Tadulako \\ Email : nurhtaufiktri@gmail.com
}

\begin{abstract}
The purpose of this study is to simultaneously and partially determine and analyze the effect of accessibility and destination image toward the revisit to Tambing Lake. The variables of this research are accessibility $\left(X_{1}\right)$ and destination image $\left(X_{2}\right)$. While the dependent variable is the revisit $(Y)$. This study used the research method of causal descriptive, with the sample size of 70 people. The sampling of this research used incidental sampling technique. The data analysis method in this research used multiple linear regression analysis method. The results showed that: 1). Accessibility and destination image simultaneously have significant effect on the revisit to Tambing Lake; 2). Accessibility partially have significant effect on the revisit to Tambing Lake; 3). Destination image partially have significant effect on the revisit to Tambing Lake.
\end{abstract}

Keywords: accessibility, destination image, intention to revisit

\begin{abstract}
ABSTRAK
Tujuan penelitian ini adalah untuk mengetahui dan menganalisis pengaruh variabel aksesibilitas dan citra destinasi secara simultan dan parsial terhadap niat berkunjung kembali ke Telaga Tambing. Variabel penelitian ini yaitu aksesibilitas $\left(\mathrm{X}_{1}\right)$ dan citra destinasi $\left(\mathrm{X}_{2}\right)$. Sedangkan variabel dependen yaitu niat berkunjung kembali (Y). Metode penelitian yang digunakan adalah metode deskriptif kausal dengan jumlah sampel 70 orang. Bentuk pengambilan sampel menggunakan teknik insidental sampling. Metode analisis data yang digunakan dalam penelitian ini adalah metode analisis regresi linear berganda. Hasil penelitian menunjukan bahwa: 1). Aksesibilitas dan citra destinasi secara simultan (serempak) berpengaruh signifikan terhadap niat berkunjung kembali ke Telaga Tambing; 2). aksesibilitas secara parsial berpengaruh signifikan terhadap niat berkunjung kembali ke Telaga Tambing; 3). citra destinasi secara parsial berpengaruh signifikan terhadap niat berkunjung kembali ke Telaga Tambing.
\end{abstract}

Kata Kunci: aksesibilitas, citra destinasi, niat mengunjungi kembali

\section{PENDAHULUAN}

Perkembangan zaman saat ini, pesatnya arus informasi, perkembangan teknologi komunikasi, ilmu pengetahuan dan seni menyebabkan orang tergerak untuk melakukan perjalanan wisata ke luar daerah bahkan ke luar batas negaranya. Termasuk melakukan perjalanan wisata ke Telaga Tambing yang sedang diminati oleh wisatawan, terkhusus wisatawan lokal yang berasal dari daerah Sulawesi.

Telaga Tambing merupakan jenis wisata cagar alam (ecotourism) yang berlokasi di Desa Sedoa, Lore Utara, Kabupaten Poso. Lokasi (aksesibilitas) Telaga Tambing sangat jauh dan sulit ditemukan, sehingga menjadi hambatan bagi para wisatawan untuk dapat berkunjung ke Telaga Tambing. Selain lokasinya jauh, wisatawan yang sudah pernah berkunjung mulai mengeluhkan citra Telaga Tambing sebagai wisata cagar alam mulai terkikis seiring dengan terus bertambahnya kunjungan wisatawan ke Telaga Tambing.

Berdasarkan fenomena aksesibilitas yang jauh dan citra Telaga Tambing yang mulai terkikis maka perlu adanya penelitian yang bertujuan untuk mengetahui pengaruh dari lokasi dan citra Telaga Tambing dengan meneliti pengaruh aksesibilitas dan citra destinasi terhadap niat berkunjung kembali ke Telaga Tambing. 
Adapun tujuan yang ingin dicapai dalam penelitian ini adalah:

1. Untuk memaparkan pengaruh aksesibilitas dan citra destinasi terhadap niat berkunjung kembali ke Telaga Tambing.

2. Untuk memaparkan pengaruh aksesibilitas terhadap niat berkunjung kembali ke Telaga Tambing.

3. Untuk memaparkan pengaruh citra destinasi terhadap niat berkunjung kembali ke Telaga Tambing..

\section{KAJIAN LITERATURE DAN PENGEMBANGAN HIPOTESIS}

\section{Pengertian Pariwisata}

Menurut Yoeti (1996:118), Pariwisata adalah suatu perjalanan yang dilakukan untuk sementara waktu yang diselenggarakan dari suatu tempat ke tempat lain, dengan maksud bukan untuk berusaha (business) atau untuk mencari nafkah di tempat yang dikunjungi, tetapi semata-mata untuk menikmati perjalanan tersebut guna pertamasyaan dan rekreasi atau untuk memenuhi keinginan yang beraneka ragam.

\section{Pengertian Aksesibilitas}

Djoko Wijono dalam Payangan (2015:31) menjelaskan aksesibilitas adalah sarana dan prasarana yang menyebabkan wisatawan dapat mengunjungi objek/daya tarik wisata (ODTW). Suwantoro (2000:56) menyatakan bahwa aksesibilitas adalah merupakan salah satu aspek penting yang mendukung pengembangan pariwisata, karena menyangkut pengembangan lintas sektoral.

\section{Dimensi Aksesibilitas}

Aksesibilitas dapat diukur melalui dimensinya, Soekadijo (2003:107-108) mengungkapkan persyaratan aksesibilitas terdiri dari akses informasi dimana fasilitas harus mudah ditemukan dan mudah dicapai, harus memiliki akses kondisi jalan yang dapat dilalui dan sampai ke tempat obyek wisata serta harus ada akhir tempat suatu perjalanan. Oleh karena itu harus selalu ada:

\section{a. Akses Informasi}

Masukan informasi yang lengkap tentunya akan menyebabkan para wisatawan semakin mudah untuk menyeleksi kawasan-kawasan yang akan dikunjungi. Informasi itu dapat berupa promosi dan publikasi.

b. Akses Kondisi Jalan Menuju Objek Wisata

Akses kondisi jalan menuju obyek wisata, dan jalan akses itu harus berhubungan dengan prasarana umum. Kondisi jalan umum dan jalan akses menentukan aksesibilitas suatu obyek wisata. Aksesibilitas ini merupakan syarat yang penting sekali untuk obyek wisata.

c. Tempat Akhir Perjalanan

Selanjutnya sebagai tempat akhir perjalanan, di tempat objek wisata harus ada terminal, setidaktidaknya tempat parkir. Baik jalan akses maupun tempat parkir harus sesuai dengan kebutuhan yaitu sesuai dengan jumlah wisatawan yang diharapkan kedatangannya dan jenis serta jumlah kendaraan yang diperkirakan akan digunakan oleh para wisatawan.

\section{Pengertian Citra Destinasi}

Menurut Coshall (2002:1116) menyatakan citra destinasi merupakan gambaran, pikiran, kepercayaan, perasaaan dan persepsi terhadap suatu destinasi. Menurut Coshall (2002:89) yang menyatakan bahwa citra destinasi merupakan kesan wisatawan secara umum terhadap suatu destinasi wisata.

\section{Dimensi Citra Destinasi}

Terdapat tiga dimensi dari citra destinasi menurut Hailin, dkk (2011:470) yaitu sebagai berikut:

a. Cognitive destination image (citra destinasi kognitif) 
Citra destinasi kognitif, terdiri dari kualitas pengalaman yang didapat oleh para wisatawan, atraksi wisata yang ada di suatu destinasi, lingkungan dan infrastruktur di lingkungan tersebut, hiburan dan tradisi budaya dari destinasi tersebut.

b. Unique image (citra destinasi yang unik)

Citra destinasi yang unik, terdiri dari lingkungan alam, kemenarikan suatu destinasi dan atraksi lokal yang ada didestinasi tersebut.

c. Affective destination image (citra destinasi efektif)

Citra destinasi efektif, terdiri dari perasaan yang menyenangkan, membangkitkan, santai dan menarik ketika di suatu destinasi.

\section{Niat Berkunjung Kembali}

Baker dan Crompton (2000) menyatakan niat berkunjung kembali adalah niat dan keinginan berkunjung lebih sering. Niat kunjungan ulang didefiniskan sebagai minat beli kembali (purchase intention) yaitu keinginan yang kuat untuk membeli kembali (Fullerton dan Taylor, 2000).

\section{Kerangka Pemikiran}

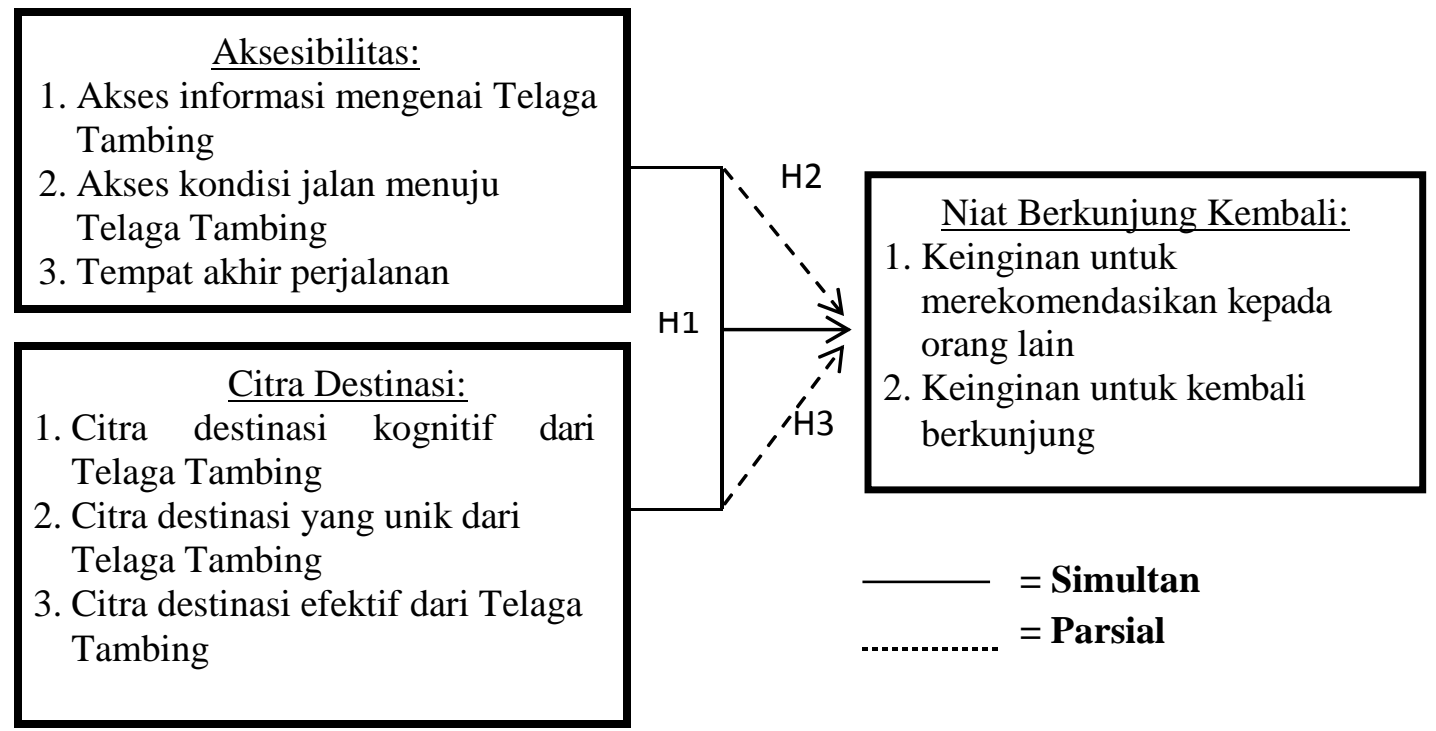

Gambar 1. Kerangka Pemikiran

\section{Hipotesis}

Dugaan sementara yang diajukan oleh peneliti dalam penelitian ini yaitu:

H1 : Semua variabel aksesibilitas dan citra destinasi secara simultan berpengaruh signifikan terhadap niat berkunjung kembali ke Telaga Tambing.

$\mathrm{H} 2$ : Variabel aksesibilitas berpengaruh signifikan terhadap niat berkunjung kembali ke Telaga Tambing.

H3 : Variabel citra destinasi berpengaruh signifikan terhadap niat berkunjung kembali ke Telaga Tambing.

\section{METODE PENELITIAN}

Jenis penilitian ini adalah penelitian deskriptif dan kausal, menurut Sugiyono (2016:11) penelitian deskriptif adalah penelitian yang dilakukan untuk mengetahui nilai variabel mandiri, baik satu variabel atau lebih (independen) tanpa membuat perbandingan atau menghubungkan antara variabel satu 
dengan variabel yang lain. Menurut Sugiyono (2016:12) Hubungan kausal adalah hubungan sebab akibat, X memengaruhi Y atau bila X maka Y. Adapun menurut Sugiyono (2013:38) objek penelitian (variabel penelitian) adalah segala sesuatu yang berbentuk apa saja yang ditetapkan oleh peneliti untuk dipelajari sehingga informasi tentang hal tersebut, kemudian ditarik kesimpulannya. Berdasarkan pemahaman tersebut, dalam konteks penelitian ini yang dimaksud objek penelitian yaitu pengaruh aksesibilitas dan citra destinasi sebagai variabel yang mempengaruhi (independen) sedangkan variabel yang dipengaruhi (dependen) ialah niat berkunjung kembali ke Telaga Tambing.

Populasi adalah wilayah generalisasi yang terdiri dari objek atau subjek yang mempunyai kualitas dan karakteristik tertentu yang ditetapkan oleh peneliti untuk dipelajari dan kemudian ditarik kesimpulannya (Sugiyono,2016:90). Populasi dalam penelitian ini adalah seluruh wisatawan yang sedang berkunjung ke destinasi wisata Telaga Tambing. Metode pengambilan sampel yang digunakan dalam penelitian ini adalah non-probability sampling dan menggunakan teknik sampling insidental yaitu teknik penentuan sampel berdasarkan kebetulan, yaitu siapa saja yang secara kebetulan/insedental bertemu dengan peneliti dapat digunakan sebagai sampel, bila dipandang orang yang kebetulan di temui itu cocok sebagai sumber data. Adapun kriteria responden yang dijadikan sampel pada penelitian ini agar dipandang cocok sebagai sumber data adalah sebagai berikut:

1. Bersedia mengisi kuesioner yang diberikan

2. Minimal berusia 15 tahun

Jumlah sampel yang akan diambil untuk mewakili populasi dalam penelitian ini sebanyak 70 sampel. Penentuan sampel sebanyak 70 responden, ini didasarkan pada teori teori Roscoe dalam Sugiyono (2016:102-103) bila dalam penelitian akan melakukan analisis dengan multivariate (korelasi atau regresi berganda misalnya), maka jumlah anggota sampel minimal 10 kali dari jumlah variabel yang diteliti (independen + dependen).

\section{Pengujian Instrumen Penelitian}

Sebelum data dikumpulkan dan diolah, maka sebelumnya peneliti perlu melakukan uji coba instrumen terlebih dahulu, guna mengetahui tingkat validitas dan reliabilitas suatu instrument

1. Uji Validitas

Ghozali (2013:52) uji validitas digunakan untuk mengukur sah atau valid tidaknya suatu kuesioner. Syarat minimum untuk dianggap memenuhi syarat adalah $\mathrm{r}=0.3$. Jadi, korelasi antara butir dengan skor total kurang dari 0.3 maka butir dalam instrument tersebut dinyatakan tidak valid.

2. Uji Reliabilitas

Sunyoto (2013:81) uji reliabilitas adalah alat untuk mengukur suatu kuesioner yang merupakan indikator dari variabel atau konstruk. Butir pertanyaan dikatakan reliabel atau handal apabila jawaban seseorang terhadap pertanyaan adalah konsisten. Suatu konstruk atau variabel dikatakan reliabel jika memberikan nilai Cronbach Alpha $>0.60$.

\section{Metode Analisis}

1. Uji Normalitas

Uji Normallitas digunakan untuk menguji apakah dalam sebuah model regresi variabel (pengganggu) dependen dan independen atau keduanya memiliki distribusi normal (Ghozali, 2013:160). Model regresi yang baik adalah distribusi data normal atau mendekati normal. Deteksi normalitas dilakukan dengan melihat penyebaran data (titik) pada sumbu diagonal dan grafik.

2. Uji Multikolinieritas

Uji Multikolinieritas digunakan untuk menguji apakah model regresi ditemukan adanya kolerasi antara variabel bebas independen. Model regresi yang baik seharusnya antara variabel independen tidak terjadi korelasi antara variabel independen (Ghozali, 2013:105). 
3. Uji Heteroskedastisitas

Menurut Ghozali (2013:139) uji heteroskedastisitas yaitu untuk menguji apakah dalam model regresi terjadi ketidaksamaan variance dari residual satu pengamatan ke pengamatan yang lain. Jika variance dari residual satu pengamatan ke pengamatan lain tetap, maka disebut homoskedastisitas dan jika berbeda disebut heteroskedastisitas Model regresi yang baik adalah tidak terjadi heteroskedastisitas.

4. Regresi Linear Berganda

Untuk menguji pengaruh variabel aksesibilitas dan citra destinasi terhadap niat berkunjung kembali ke Telaga Tambing maka digunakan alat uji statistik yaitu regresi linear berganda yang dapat dirumuskan (Sugiyono, 2011:262):

$$
\mathbf{Y}=\mathbf{a}+\mathbf{b}_{1} \mathbf{X}_{1}+\mathbf{b}_{2} \mathbf{X}_{2}+\mathbf{e}
$$

Keterangan:

$\begin{array}{ll}\mathrm{a} & =\text { Konstanta } \\ \mathrm{Y} & =\text { Niat Berkunjung Kembali ke Telaga Tambing } \\ \mathrm{b}_{1}, \mathrm{~b}_{2}, \mathrm{~b}_{3} & =\text { Koefisien Regresi masing-masing Variabel } \\ \mathrm{X}_{1} & =\text { Aksesibilitas ke Telaga Tambing } \\ \mathrm{X}_{2} & =\text { Citra Destinasi Telaga Tambing } \\ \mathrm{e} & =\text { Term Error (Tingkat Kesalahan) }\end{array}$

\section{HASIL DAN PEMBAHASAN}

\section{Hasil Uji Validitas dan Reliabilitas}

Berikut ini adalah hasil uji validitas dan reliabilitas atas item pernyataan yang terdapat dalam kuesioner penelitian terhadap variabel aksesibilitas (X1), citra destinasi (X2) dan niat berkunjung kembali (Y). Adapun hasilnya disajikan dalam tabel berikut:

Tabel 1. Hasil Uji Validitas dan Reliabilitas Instrumen Penelitian

\begin{tabular}{cccccc}
\hline Variabel & Item & $\begin{array}{c}\text { Total } \\
\text { Correlation }\end{array}$ & Ket & $\begin{array}{c}\text { Cronbach } \\
\text { Alpha }\end{array}$ & Ket \\
\hline & X1.1 & 0,553 & Valid & & \\
X1.2 & 0,458 & Valid & & \\
& X1.3 & 0,554 & Valid & & \\
X1.4 & 0,649 & Valid & & Reliabel \\
& X1.5 & 0,756 & Valid & & \\
Aksesibilitas & X1.6 & 0,407 & Valid & & \\
(X1) & X1.7 & 0,364 & Valid & 0,876 & \\
& X1.8 & 0,585 & Valid & & \\
& X1.9 & 0,788 & Valid & & \\
& X1.10 & 0,372 & Valid & & \\
& X1.11 & 0,668 & Valid & & \\
& X1.12 & 0,538 & Valid & & \\
X1.13 & 0,586 & Valid & & \\
Citra Destinasi & X2.1 & 0,549 & Valid & & \\
X2) & X2.3 & 0,778 & Valid & 0,892 & \\
& X2.4 & 0,607 & Valid & & \\
& 0,426 & Valid & & \\
\hline
\end{tabular}




\begin{tabular}{cccccc}
\hline Variabel & Item & $\begin{array}{c}\text { Total } \\
\text { Correlation }\end{array}$ & Ket & $\begin{array}{c}\text { Cronbach } \\
\text { Alpha }\end{array}$ & Ket \\
\hline & X2.5 & 0,349 & Valid & & \\
X2.6 & 0,391 & Valid & & \\
X2.7 & 0,468 & Valid & & \\
X2.8 & 0,732 & Valid & & \\
X2.9 & 0,602 & Valid & & \\
& X2.10 & 0,766 & Valid & & \\
& X2.11 & 0,469 & Valid & & \\
X2.12 & 0,693 & Valid & & \\
& X2.13 & 0,640 & Valid & & \\
Niat Berkunjung & X2.14 & 0,617 & Valid & & \\
Kembali & X2.15 & 0,422 & Valid & & \\
(Y) & X3.2 & 0,583 & Valid & & \\
& X3.3 & 0,642 & Valid & 0,688 & \\
\end{tabular}

Berdasarkan hasil uji validitas dan reliabilitas diperoleh bahwa seluruh variabel memiliki koefisien Cronbach Alpha (a) lebih besar dari 0,60 sehingga berdasarkan syarat minimum reliabilitas lebih besar dari 0,60 maka seluruh variabel yang digunakan reliabel dan dapat digunakan dalam penelitian ini. Sedangkan uji validitas terhadap seluruh variabel juga menunjukan nilai koefisien korelasi yang lebih besar dari 0,30 sehingga item pernyataan yang ada valid untuk digunakan.

\section{Hasil Uji Regresi Linear Berganda}

Penelitian ini menggunakan analisis regresi linear berganda dengan tujuan untuk menguji pengaruh antara variabel aksesibilitas dan citra destinasi terhadap niat berkunjung kembali ke Telaga Tambing. Untuk lebih jelasnya hasil analisis regresi linear berganda dapat dilihat pada tabel berikut:

Tabel 2. Hasil Uji Regresi Linear Berganda

\begin{tabular}{|c|c|c|c|c|c|}
\hline \multicolumn{6}{|c|}{ Dependen Variabel Y = Niat Berkunjung Kembali } \\
\hline \multirow{2}{*}{$\begin{array}{c}\text { Variabel } \\
\text { Independen }\end{array}$} & \multicolumn{2}{|c|}{$\begin{array}{c}\text { Unstandardized } \\
\text { Coefficients }\end{array}$} & \multirow{2}{*}{ 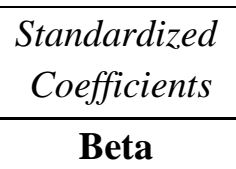 } & \multirow[t]{2}{*}{$\mathrm{T}$} & \multirow[t]{2}{*}{ Sig } \\
\hline & $\mathbf{B}$ & Std. Error & & & \\
\hline (Constant) & 1,930 & ,300 & & 6,425 &, 000 \\
\hline $\begin{array}{c}\mathrm{X} 1 \\
\text { (Aksesibilitas) }\end{array}$ & 399 & 087 & ,479 & 4,608 & ,000 \\
\hline $\begin{array}{c}\text { X2 } \\
(\text { Citra } \\
\text { Destinasi) }\end{array}$ & ,224 & ,079 & ,294 & 2,828 & ,006 \\
\hline Multiple R & \multicolumn{2}{|c|}{$=0,674^{\mathrm{a}}$} & \multicolumn{2}{|c|}{ Sig. $F=0,000$} & \\
\hline Adjusted R Square & \multicolumn{2}{|c|}{$=0,438$} & \multicolumn{3}{|c|}{$\alpha=0,05$ tingkat kepercayaan $95 \%$} \\
\hline
\end{tabular}

Berdasarkan tabel 2 di atas, dapat di tulis dalam bentuk persamaan regresi linear berganda. Lebih jelasnya bentuk persamaan tersebut dapat dilihat sebagai berikut: 


$$
Y=1,930+0,399 X_{1}+0,224 X_{2}+e
$$

Berdasarkan penjabaran di atas menunjukkan bahwa, variabel independen yang dianalisis yaitu variabel $\left(\mathrm{X}_{1}\right.$ dan $\left.\mathrm{X}_{2}\right)$ memberikan pengaruh positif terhadap variabel dependen ( $\mathrm{Y}$ ) yaitu niat berkunjung kembali ke Telaga Tambing. Agar lebih jelasnya penjelasan bentuk persamaan tersebut dapat dilihat berikut ini:

1. Nilai konstanta sebesar 1,930 artinya jika variabel (aksesibilitas dan citra destinasi) bernilai 0 atau konstan, maka variabel dependen (niat berkunjung kembali) nilainya sebesar 1,930. Setiap ada kenaikan pada variabel independen sebesar satu satuan maka akan meningkatkan variabel dependen sebesar nilai koefisiensi beta masing-masing variabel independen dikalikan dengan besarnya kenaikan yang terjadi.

2. Koefisien regresi dimensi aksesibilitas $\left(\mathrm{X}_{1}\right)$ sebesar 0,399 , artinya bahwa pengaruh variabel aksesibilitas terhadap niat berkunjung kembali ke Telaga Tambing adalah bersifat positif dan jika skor variabel aksesibilitas meningkat maka niat berkunjung kembali juga akan meningkat.

3. Koefisien regresi dimensi citra destinasi $\left(\mathrm{X}_{2}\right) \quad 0,224$, artinya bahwa pengaruh variabel citra destinasi terhadap niat berkunjung kembali adalah bersifat positif dan jika skor variabel citra destinasi meningkat maka niat berkunjung kembali juga akan meningkat.

\section{Hasil Pengujian Hipotesis}

\section{Hasil Pengujian Hipotesis Secara Simultan (Uji F)}

Tahap selanjutnya adalah menguji signifikan hubungan atau uji $\mathrm{F}$ antara variabel penelitian yaitu akesibilitas $\left(\mathrm{X}_{1}\right)$ dan citra destinasi $\left(\mathrm{X}_{2}\right)$ terhadap niat berkunjung kembali $(\mathrm{Y})$ dengan perhitungan menggunakan SPSS 16.0 dengan hasil sebagai berikut:

Tabel 3. Hasil Uji F (Simultan)

\begin{tabular}{|c|c|c|c|c|c|c|}
\hline \multicolumn{7}{|c|}{ ANOVA $^{\mathrm{a}}$} \\
\hline & Model & $\begin{array}{l}\text { Sum of } \\
\text { Squares }\end{array}$ & Df & Mean Square & $\mathrm{F}$ & Sig. \\
\hline \multirow{3}{*}{1} & Regression & 2,797 & 2 & 1,399 & 27,931 &, $000^{\mathrm{b}}$ \\
\hline & Residual & 3,355 & 67 &, 050 & & \\
\hline & Total & 6,152 & 69 & & & \\
\hline
\end{tabular}

Berdasarkan tabel 3 di atas, diperoleh nilai signifikansi $\mathrm{F}$ yaitu $0,000<\alpha=0,05$ dengan tingkat kepercayaan 95\%. Maka dari itu dapat dinyatakan bahwa secara simultan variabel aksesibilitas dan citra destinasi berpengaruh signifikan terhadap niat berkunjung kembali ke Telaga Tambing, dengan demikian $\mathrm{H}_{1}$ diterima dan $\mathrm{H}_{0}$ ditolak.

\section{Hasil Pengujian Hipotesis Secara parsial (Uji t)}

Hasil Uji t adalah untuk mengetahui apakah variabel $\left(\mathrm{X}_{1}\right.$ atau $\left.\mathrm{X}_{2}\right)$ secara parsial atau sediri-sendiri berpengaruh terhadap variabel Y. Untuk lebih jelasnya hasil dapat dilihat pada tabel berikut: 
Tabel 4. Hasil Uji t (Parsial)

\begin{tabular}{cccc}
\hline & Model & T & Sig \\
\hline & (Constant $)$ & 6.425 & .000 \\
1 & $\mathrm{X}_{1}$ & 4.608 & .000 \\
& $\mathrm{X}_{2}$ & 2.828 & .006 \\
& & &
\end{tabular}

Berdasarkan tabel 4 di atas hasil uji t pengujian variabel $\left(\mathrm{X}_{1}\right.$ atau $\left.\mathrm{X}_{2}\right)$ terhadap $\mathrm{Y}$ dijelaskan sebagai berikut:

1. Hasil Pengujian Hipotesis $\mathrm{X}_{1}$ terhadap $\mathrm{Y}$

Hipotesis kedua $\left(\mathrm{H}_{2}\right)$ untuk mengetahui apakah aksesibilitas $\left(\mathrm{X}_{1}\right)$ secara parsial berpengaruh signifikan terhadap niat berkunjung kembali ke Telaga Tambing. Hasil penelitian ini adalah $\mathrm{H}_{2}$ diterima dan $\mathrm{H}_{0}$ ditolak. Pembuktian atas hasil ini nampak pada nilai signifikansi $0.000<5 \%(0.05)$. Hasil uji statistik ini mengandung arti bahwa variabel aksesibilitas memiliki pengaruh dalam memengaruhi niat wisatawan untuk berkunjung kembali.

2. Hasil Pengujian Hipotesis Hasil $\mathrm{X}_{2}$ terhadap $\mathrm{Y}$

Hipotesis ketiga $\left(\mathrm{H}_{3}\right)$ untuk mengetahui apakah citra destinasi $\left(\mathrm{X}_{2}\right)$ secara parsial berpengaruh signifikan terhadap niat berkunjung ke Telaga Tambing. Hasil penelitian ini adalah $\mathrm{H}_{3}$ diterima dan $\mathrm{H}_{0}$ ditolak. Pembuktian atas hasil ini nampak pada nilai signifikansi $0.006<5 \%(0.05)$. Hasil uji statistik ini mengandung arti bahwa variabel citra destinasi berperan memiliki pengaruh dalam memengaruhi niat wisatawan untuk berkunjung kembali.

\section{Pembahasan atau Hasil Analisis}

\section{Analisis Secara Simultan}

Berdasarkan hasil pengujian serta analisis yang telah dilakukan pada penelitian ini membuktikan bahwa variabel aksesibilitas (akses informasi, akses kondisi jalan dan tempat akhir perjalanan) dan citra destinasi (citra destinasi kognitif, citra destinasi yang unik dan citra destinasi efektif) secara simultan (serempak) berpengaruh signifikan terhadap niat berkunjung kembali ke Telaga Tambing.

Berdasarkan tabel rekapitulasi regresi linear berganda dapat dilihat pengaruh hasil uji determinasi Adjusted $R$ Square sebesar 0,438. Nilai tersebut dapat diartikan bahwa aksesibilitas dan citra destinasi mempunyai konstribusi secara bersama-sama sebesar $43,8 \%$ terhadap variabel terikat yaitu terhadap niat berkunjung kembali ke Telaga Tambing. Sedangkan sisanya $(100 \%-43,8 \%=56,2 \%)$, dipengaruhi oleh variabel lain yang tidak diteliti dalam penelitian ini.

\section{Analisis Secara Parsial}

\section{Variabel Aksesibilitas $\left(\mathbf{X}_{1}\right)$}

Aksesibilitas memiliki peranan dalam memengaruhi niat berkunjung kembali, aksesibilitas merupakan sarana dan prasarana yang menyebabkan wisatawan dapat mengunjungi objek/daya tarik wisata. Hasil penelitian ini menunjukan bahwa variabel aksesibilitas berpengaruh positif dan signifikan terhadap niat berkunjung kembali. Adapun indikator-indikator yang digunakan untuk mengukur variabel aksesibilitas adalah kelengkapan informasi, kemudahan mendapatkan informasi, kondisi jalan, prasarana umum, lokasi objek wisata, jarak tempuh, biaya yang dikeluarkan.

Berdasarkan hasil penelitian maka dapat diinterpretasikan bahwa secara umum responden mengakui variabel aksesibilitas menuju ke Telaga Tambing memudahkan wisatawan ketika ingin berkunjung dan memengaruhi niat berkunjung kembali. Hal ini dibuktikan dari hasil penelitian yang menjelaskan bahwa pengunjung Telaga Tambing menganggap jalan yang dilalui menuju lokasi Telaga Tambing mudah untuk di tempuh oleh wisatawan dan lokasi Telaga Tambing mudah ditemukan 
pengunjung karena pengunjung juga setuju dengan indikator lokasi Telaga Tambing berada di pinggir jalan raya.

Responden juga menganggap waktu yang dibutuhkan untuk bisa sampai ke Telaga Tambing cukup lama karena memang lokasi Telaga Tambing sendiri dapat di tembuh sekitar $70 \mathrm{Km}$ dari Kota Palu, walaupun lokasi jauh dari pusat kota responden mudah untuk menemukan lokasi Telaga Tambing. Selain waktu yang dibutuhkan, responden mudah untuk mendapatkan informasi mengenai Telaga Tambing melalui berbagai media seperti: web resmi dari pengelola Telaga Tambing, media sosial, informasi dari mulut ke mulut sehingga indikator-indikator yang diberikan kepada responden akan memengaruhi niat berkunjung kembali wisatawan ke Telaga Tambing. Maka semakin mudah akses termasuk kemuduahan jalan yang dilalui, kemudahan mendapatkan informasi, mudah menemukan lokasi, lokasi berada di pinggir jalan raya maka akan meperkuat niat wisatawan untuk berkunjung kembali ke Telaga Tambing.

Hasil penelitian ini sejalan dengan teori yang menyatakan bahwa kondisi jalan umum dan jalan akses menentukan aksesibilitas suatu obyek wisata. Aksesibilitas merupakan syarat yang penting sekali untuk objek wisata (Soekadijo, 2003:107-108). Pengunjung menganggap jalan menuju Telaga Tambing mudah untuk di tempuh sehingga pengunjung tidak perlu mengeluarkan tenaga lebih untuk bisa sampai ke Telaga Tambing. Yoeti dalam Andayani (2014:3) menjelaskan produk pariwisata harus memenuhi unsur-unsur, salah satunya unsur kemudahan untuk mencapai daerah tujuan wisata.

Hasil penelitian menunjukan bahwa variabel aksesibilitas yang terdiri dari akses informasi, kondisi jalan dan tempat akhir perjalanan berpengaruh positif dan signifikan terhadap niat berkunjung kembali ke Telaga Tambing. Hal ini juga sejalan dengan penelitian terdahulu yang dilakukan oleh Alffatory Rheza Syahrul (2015), yang menyatakan bahwa aksesibilitas berpengaruh signifikan terhadap keputusan wisatawan asing untuk berkunjung kembali. Lokasi yang strategis, kemudahan akses informasi dan komunikasi, keamanan yang terjamin dan transportasi yang lancar merupakan salah satu faktor yang penting untuk meningkatkan jumlah wisatawan. Aksesibilitas berperan penting terhadap niat berkunjung kembali wisatawan, sebab aksesibilitas menjadi salah satu variabel yang menentukan keinginan wisatawan untuk berkunjung kembali ke suatu destinasi wisata.

\section{Variabel Citra Destinasi $\left(\mathbf{X}_{2}\right)$}

Citra destinasi memiliki peranan dalam memengaruhi niat berkunjung kembali, citra destinasi merupakan gambaran dan persepsi wisatawan terhadap suatu destinasi yang dapat memengaruhi keinginan wisatawan untuk berkunjung ke sauatu destinasi wisata. Hasil penelitian ini menunjukan bahwa variabel citra destinasi berpengaruh positif dan signifikan terhadap niat berkunjung kembali. Adapun indikator-indikator yang digunakan untuk mengukur variabel citra destinasi adalah hiburan dan kegiatan yang bisa dilakukan di Telaga Tambing, lingkungan dan infrastruktur di lingkungan wisata, kualitas pengalaman, lingkungan alam, kemenarikan suatu destinasi, perasaan menyenangkan dan perasaan nyaman.

Berdasarkan hasil penelitian maka dapat diinterpretasikan bahwa secara umum responden mengakui variabel citra destinasi Telaga Tambing masih berkualitas sehingga dapat memengaruhi niat berkunjung kembali wisatawan. Hal ini dibuktikan dengan kesan yang didapatkan oleh wisatawan setelah berkunjung ke Telaga Tambing, wisatawan mendapatkan kesan yang baik setelah berkunjung dan menyetujui jika Telaga Tambing masih menjadi destinasi yang menarik untuk dikunjungi oleh wisatawan. Selain itu wisatawan juga menyetujui Telaga Tambing memiliki keunikan yang dapat ditawarkan kepada wisatawan salah satunya pemandangan alam dan suhu dingin yang unik.

Kesan yang didapatkan wisatawan berasal dari indikator aktivitas kemping yang dilakukan wisatawan selama berkunjung sehingga dapat menciptakan kesan yang baik, pemadangan alam dan suhu dingin yang bisa dinikmati di Telaga Tambing juga memberikan kesan yang baik bagi responden yang sedang berkunjung. Responden mendapatkan perasaan senang ketika berkunjung ke Telaga 
Tambing yang didapatkan dari pemandangan alam dan suhu dingin sehingga dapat memberikan perasaan senang dan nyaman dibenak wisatawan yang akan memperkuat niat wisatawan untuk berkunjung kembali ke Telaga Tambing.

Hasil penelitian ini menyatakan bahwa citra destinasi Telaga Tambing memiliki kualitas dan kesan yang baik dari wisatawan yang berkunjung sehingga wisatawan mendapatkan perasaan senang dan nyaman selama berkunjung, jika semakin baik citra dari suatu destinasi maka semakin tinggi niat untuk mengunjungi kembali suatu destinasi wisata.

Telaga Tambing mampu memberikan daya tariknya sebagai suatu destinasi kepada wisatawan sehingga dapat memberikan kesan yang baik dibenak wisatawan yang berkunjung dan wisatawan mendapatkan perasaan senang dan nyaman selama berkunjung. Semakin baik citra destinasi maka akan dapat menarik niat berperilaku untuk dapat mengunjungi obyek wisata. Selanjutnya niat berperilaku yang mempunyai indikator responden memiliki keinginan untuk berkunjung kembali, merekomendasikan kepada pihak lain dan berkunjung kembali suatu objek wisata.

Hasil penelitian ini menunjukan bahwa variabel citra destinasi yang terdiri dari beberapa dimensi yaitu citra destinasi kognitif, citra destinasi yang unik dan citra destinasi efektif berpengaruh secara positif dan signifikan terhadap niat berkunjung kembali ke Telaga Tambing. Hal ini sejalan dengan penelitian terdahulu yang dilakukan oleh Naili Farida (2013), yang menyatakan bahwa pengaruh citra destinasi terhadap niat berperilaku adalah positif dan signifikan.

Penelitian ini diperkuat dengan hasil penelitian yang dilakukan oleh Mulyana dan Devi (2016) dalam penelitiannya menyatakan bahwa hipotesis citra destinasi terhadap niat mengunjungi kembali diterima dan menyatakan bahwa citra berhubungan signifikan terhadap niat berkunjung kembali. Cahyanti dan Widiya (2017) dalam penelitiannya mendapatkan hasil bahwa citra destinasi berpengaruh signifikan terhadap niat berkunjung wisatawan. Citra destinasi mememiliki peranan penting dalam memengaruhi niat berkunjung kembali wisatawan, semakin baik citra dari suatu destinasi atau tempat wisata maka niat wisatawan untuk kembali berkunjung semakin tinggi dan apabila citra suatu destinasi kurang baik maka niat untuk berkunjung juga rendah.

\section{PENUTUP}

\section{Kesimpulan}

Berdasarkan hasil penelitian yang telah dijabarkan, maka diperoleh kesimpulan mengenai pengaruh aksesibilitas dan citra destinasi terhadap niat berkunjung kembali ke Telaga Tambing:

1. Aksesibilitas dan citra destinasi secara simultan berpengaruh signifikan terhadap niat berkunjung kembali ke Telaga Tambing.

2. Aksesibilitas secara parsial berpengaruh signifikan terhadap niat berkunjung kembali ke Telaga Tambing.

3. Citra destinasi secara parsial berpengaruh signifikan terhadap niat berkunjung kembali ke Telaga Tambing.

\section{Saran}

Berdasarkan kesimpulan yang telah diuraikan sebelumnya, maka saran-saran yang tepat menyangkut kegunaan penelitian ini dapat diuraikan sebagai berikut :

1. Kepada Balai Besar Taman Nasional Lore Lindu (BBTNLL) agar bisa bekerjasama dengan dinas Pariwisata untuk dapat menyediakan transportasi umum yang khusus mengangkut wisatawan untuk bisa sampai ke Telaga Tambing dengan fasilitas yang mendukung kenyamanan wisatawan selama perjalanan.

2. Kepada pihak BBTNLL dan Dinas Pariwisata harus bisa menyediakan ruang bagi industri pariwisata untuk mengelola kebutuhan wisatawan seperti dalam bentuk paket wisata yang didalamnya sudah memenuhi transportasi, penyediaan tempat menginap, penyediaan makanan dan 
pemandu wisata, sehingga dapat memudahkan dan meminimalisir biaya yang dikeluarkan wisatawan ketika ingin berkunjung ke Telaga Tambing.

3. Kepada pihak BBTNL atau Pemerintah Daerah untuk memperbaiki kualitas jalan yang dilalui menuju Telaga Tambing agar wisatawan merasa nyaman ketika melakukan perjalanan ke Telaga Tambing.

4. Kepada pihak BBTNL untuk meningkatkan promosi mengenai keberadaan flora dan fauna endemik Telaga Tambing kepada wisatawan dan menyediakan jasa pemandu yang bertugas memandu wisatawan untuk melihat flora dan fauna yang ada di Telaga Tambing, sehingga wisatawan lebih mudah ketika ingin melihat flora dan fauna yang ada di Telaga Tambing.

5. Kepada peneliti selanjutnya disarankan untuk menggunakan variabel lain seperti variabel daya tarik wisata, atraksi wisata, fasilitas wisata atau promosi pariwisata, selain yang digunakan dalam penelitian ini, sehingga lebih dapat mengulas masalah-masalah yang ada di Telaga Tambing. Selain itu diharapkan untuk menggunakan jenis penelitian kualitatif, agar lebih menjelaskan dan menyelesaikan permasalahan yang terdapat di Telaga Tambing.

\section{REFERENSI}

Andayani Ni Luh Henny. (2014). Manajemen Pemasaran Pariwisata. Yogyakarta: Graha Ilmu.

Baker, D. A. and Crompton, J. L. 2000. Quality, satisfaction and behavioral intentions. Annals of Tourism Research, Vol 27(3), 785-804.

Choshall, J.T. (2002). Measurement of Torists Images: The Repetory Grid Approach, Journal Travel Research, Vol. 39, pp. 85-9.

Cahyanti Mega dan Widiya Dewi, (2017). Meningkatkan Niat Berkunjung pada Generasi Muda Melalui Citra Destinasi dan Daya Tarik Kampung Wisata. STIE AsiA, Malang. Jurnal JIBEKA, Vol.11,No.1.

Fullerton, G., and Taylor,S. (2000). Service Quality and Satisfaction with Service Reasearch.

Farida Naili, (2013). Pengaruh Kualitas Layanan, Fasilitas Wisata, Promosi Terhadap Citra Destinasi dan Niat Berprilaku Pada Obyek Wisata Karimunjawa Kabupaten Jepara. Universitas Diponegoro, Semarang. Jurnal Graduasi, Vol. 31.

Ghozali, Imam. (2013). Aplikasi Analisis Multivariat Dengan Program IBM SPSS 21, Edisi 7. Semarang, Universitas Diponegoro.

Mulyana Andy dan Devi Ayuni, (2016). Hubungan Antara Kualitas Jasa, Citra Destinasi, Kepuasan Pengunjung dan Niat Berkunjung Kembali Taman Wisata Air Terjun Di Bogor. Universitas Terbuka, Bogor. Jurnal Manajemen Indonesia, Vol.16, No.3.

Mahasuwerachai, Oatcharaporn, Hailin Qu.(2011). The Impact Of Destination Image On Value, Satisfaction And Loyalty: Moderating Effects Of Turists Characteristicts And Involvement" School of Hotel and Restorant Administration Oklahoma State University.

Payangan Otto R. (2015). Pemasaran Jasa Pariwisata, Bogor: PT Penerbit IPB Press.

R.G. Soekadijo. (2003). Anatomi Pariwisata, Jakarta: Gramedia Pustaka Utama.

Suwantoro, Gamal. (2000). Dasar-dasar Pariwisata, Yogyakarta: Penerbit Andi.

Soekadijo, R.G. (2003). Anatomi Pariwisata, Jakarta: PT Gramedia Pustaka.

Sugiyono. (2011). Metode Penelitian Kuantitatif, Kualitatif dan R\&D, Bandung: Afabeta.

Sugiyono. (2013). Statistika Untuk Penelitian, Bandung: Alfabeta. 
Sugiyono. (2016). Metode Penelitian Administrasi dilengkapi Metode R\&G. Bandung: Alfabeta.

Sunyoto, Danang. (2013). Metodologi Penelitian Akuntansi, Bandung: PT Refika Aditama.

Syahrul Alfattory Rheza, (2015). Pengaruh Daya Tarik, Fasilitas dan Aksesibilitas Terhadap Keputusan Wisatawan Asing Berkunjung Kembali ke Aloita Resort di Kab. Kep. Mentawai. STKIP PGRI, Sumatera Barat. Jurnal Pelangi, Vol. 7, No. 1.

Yoeti, A. OKA. (1996). Pengantar Ilmu Pariwisata. Bandung: Angkasa. 